\title{
POTENSI PERTAMBANGAN DAN ANCAMAN KEBENCANAAN SEBAGAI DATA PENUNJANG PENYUSUNAN TATA RUANG WILAYAH \\ DI KECAMATAN WADASLINTANG, KABUPATEN WONOSOBO, PROVINSI JAWA TENGAH
}

\author{
MINING AND HAZARD POTENTIAL AS SUPPORTING DATA \\ FOR TERRITORIAL ARRANGEMENT AT WADASLINTANG DISTRICT, \\ WONOSOBO REGENCY, PROVINCE OF CENTRAL JAVA
}

\author{
Chusni Ansori, Puguh Dwi Raharjo, dan Fitriany Amalia Wardhani \\ Balai Informasi dan Konservasi Kebumian Karangsambung, LIPI \\ chus001@lipi.go.id, ansorich.63@gmail.com
}

\begin{abstract}
ABSTRAK
Kecamatan Wadaslintang mempunyai potensi pertambangan berupa andesit, diabas, batupasir, sirtu, tanah urug, breksi, batu mulia dan kaolin. Sejalan dengan peningkatan pembangunan, kebutuhan bahan tambang untuk memenuhi pembangunan bertambah secara signifikan, namun ketersediaan wilayah pertambangan tidak terakomodasi dalam Rencana Tata Ruang Wilayah. Paradigma pembangunan saat ini adalah pembangunan berkelanjutan sehingga penambangan yang dilakukan juga harus memperhatikan aspek kebencanaan. Untuk dapat mengakomodasi kepentingan penambangan dalam tata ruang wilayah, maka dilakukan kajian ini.
\end{abstract}

Penelitian bahan tambang dilakukan dengan survei lapangan dan analisis laboratorium (petrografi, geokimia, difraksi sinar $\mathrm{X}$, dan sifat fisik batuan) yang menghasilkan peta sebaran dan kualitas bahan tambang. Sedangkan penelitian kebencanaan dilakukan melalui survei lapangan serta analisis Citra Landsat menggunakan metode Analytical Hierarchy Process (AHP), sehingga didapatkan peta ancaman bencana. Peta sebaran bahan tambang dan peta ancaman bencana dilakukan proses tumpang susun, sehingga menghasilkan peta wilayah pertambangan.

Kaolin tersebar pada area 17,26 ha, setelah dilakukan proses tumpang susun, maka wilayah yang layak tambang menjadi 14,76 ha (wilayah dengan tingkat ancaman bencana rendah dan sedang). Diabas tersebar 41,84 ha, mengalami penciutan menjadi 35,29 ha. Kalkarenit seluas 22,51 ha menjadi 5,88 ha; breksi andesit seluas $1.440,6$ ha menjadi 838,92 ha, tanah merah 55,06 ha menjadi 32,29 ha, batupasir 737,6 ha menjadi 523,4 ha. Wilayah pertambangan yang dihasilkan dari proses tumpang susun antara peta ancaman bencana dengan peta potesi tambang lebih layak diterapkan untuk mengurangi resiko yang terjadi akibat penambangan.

Kata kunci: Wonosobo, Wadaslintang, potensi tambang, ancaman bencana, wilayah tambang

\section{ABSTRACT}

Wadaslintang District has the potential of mining materials such as andesite, diabase, sandstone, sirtu, red soil, breccias, precious stones and kaolin. In line with the increase of regional development, the need for mining materials has increased significantly but the availability of mining areas is not accommodated in the regional planning (RTRW) of the study area. The current development paradigm is sustainable development so that mining 
should also pay attention to the disaster aspect. This study aims to accommodate the mining interests in the regional planning.

This research is conducted through field surveys and laboratory analysis (petrography, geochemistry, $X R D$, rock physical properties) resulting in distribution maps and quality of mining materials. While disaster research is carried out through field survey and Landsat Image analysis using AHP method to obtain the map of disaster threat. The distribution map of mining materials and maps of disaster threats is then overlapped to produce a map of the mining area.

Kaolin is distributed over 17.26 ha area, after overlapping process, the area worthy of mining becomes 14.76 ha (area with low and medium disaster threat). Diabase is of 41.84 ha,downsize into 35.29 ha. Calcarenite is of 22.51 ha to 5.88 ha; andesite breccia is of 1440.6 ha to 838.92 ha, red soil is of 55.06 ha to 32.29 ha, sandstone is of 737.6 ha to 523.4 ha. Mining areas generated from overlapping processes between disaster threat maps and mining potential maps are more likely to be applied to reduce the risks posed by mining.

Keywords: Wonosobo, Wadaslintang, mining potential, disaster threat, mining area

\section{PENDAHULUAN Latar belakang}

Kegiatan pembangunan infrastruktur tidak terlepas dari kegiatan pertambangan. Landasan hukum kegiatan penambangan antara lain berupa Undang-Undang Nomor 4 Tahun 2009 tentang Pertambangan Mineral dan Batubara serta peraturan turunannya seperti Peraturan Pemerintah Nomor 22 Tahun 2010 tentang Wilayah Pertambangan; Peraturan Pemerintah Nomor 23 Tahun 2010 tentang Pelaksanaan Kegiatan Usaha Pertambangan Mineral dan Batubara; Peraturan Pemerintah Nomor 55 Tahun 2010 tentang Pembinaan Pengawasan Penyelenggaraan Pengelolaan Usaha Pertambangan Mineral dan Batubara; dan Peraturan Pemerintah Nomor 78 tahun 2010 tentang Reklamasi dan Pasca Tambang. Berdasarkan PP Nomer 23 tahun 2010 kegiatan penambangan harus berwawasan lingkungan dan berada pada wilayah izin usaha pertambangan.Potensi bahan yang berada pada suatu wilayah harus dipetakan dan diatur dalam Wilayah Usaha Pertambangan (WUP) maupun Wilayah Pertambangan Rakyat (WPR). Keberadaan wilayah pertambangan seharusnya juga tertuang dalam dokumen Rencana Tata Ruang Wilayah (RTRW), sehingga aktivitas penambangan dapat terkendali secara legal.
Sejalan dengan perkembangan pembangunan di Kabupaten Wonosobo, peningkatan kebutuhan material tambang juga meningkat. Pada sisi lain, hingga saat ini di Kecamatan Wadaslintang hanya terdapat wilayah tambang di hulu Sungai Luk Ulo. Aktivitas penambangan yang dilakukan umumnya merupakan penambangan illegal. Komoditas tambang yang terdapat di Kabupaten Wonosobo meliputi andesit, diabas, batupasir, sirtu, tanah urug, breksi, zeolit, bentonit, kaolin, tras, tufa, napal, sekis mika, konglomerat (Anonim, 2014) Perencanaan pembangunan di Indonesia saat ini mengalami perubahan paradigma yang didasari oleh Undang-Undang nomor 26 Tahun 2007 tentang penataan ruang yaitu perencanaan pembangunan yang berkelanjutan (sustainable development). Terdapat tiga aspek yang mendasari paradigma baru ini yaitu ekonomi, sosial, dan lingkungan. Ketiga aspek ini diharapkan mampu berjalan secara bersama-sama agar terjadi keseimbangan dalam perencanaan pembangunan. Keberadaan pembangunan berkelanjutan membuat pengurangan risiko bencana menjadi salah satu aspek penting dalam penyusunan Rencana Tata Ruang Wilayah (RTRW) di Kecamatan Wadaslintang termasuk dalam penyusunan wilayah pertambangan. UU Nomor 26 Tahun 2007 tentang Penataan Ruang mengamanatkan 
bahwa proses dan prosedur penataan ruang wilayah di Indonesia harus mempertimbangkan aspek kebencanaan dan konsep mitigasi bencana.

Pada saat ini upaya manajemen bencana di Indonesia masih menitikberatkan pada tahap "saat terjadi bencana" dan "pasca bencana" saja, sehingga untuk ke depan peran dan fungsi penataan ruang sebagai aspek mitigasi bencana sebenarnya menjadi sangat strategis. Pertimbangan tersebut sebagai upaya untuk mencegah atau paling tidak dapat meminimalkan jatuh korban yang diakibatkan oleh adanya bencana (Karnawati D, 2003).

\section{Geologi Daerah penelitian}

Geologi daerah penelitian tersusun oleh kelompok batuan yang cukup kompleks berupa batuan-batuan berumur pra- Tersier hasil proses tektonik hingga batuan Kuarter yang dihasilkan dari proses aktivitas gunungapi Dieng (Gambar 1).

\section{Batuan Terbreksikan (Ktm)}

Kepingan batuan sedimen dan gunungapi terubah, granit, porfir plagioklas-kuarsa, gabro, amfibolit, serpentinit dan tuf, terbreksikan, tercampur aduk secara tektonika dan tersesarkan secara massa di atas batuan sedimen berumur Kapur. Sebagian granit dan porfir diduga berasal dari batuan beku dan sebagian lagi berasal dari tuf terkersikkan dan batuan sedimen yang terkena proses metamorfosa (Condon, W. H., Pardyanto, L., Ketner, K. B. Amin, T. C. Gafoer, S. Samodra, 1996)

\section{Formasi Totogan (Tomt)}

Formasi Karangsambung-Formasi Totogan tersusun oleh kelompok batuan sedimen yang tercampur aduk karena proses pelongsoran gaya berat yang sering dikenal dengan istilah olistostrome. Bongkah-bongkah batuan sedimen berukuran centimeter hingga ratusan meter tersebar secara acak dalam masa dasar lempung hitam bersisik (scaly clay). Pada bagian bawah, variasi fragmenya sangat heterogen dengan ukuran besar, pada bagian atas lebih homogen dengan ukuran lebih kecil, pada bagian bawah scaly clay sangat intensif terbentuk namun pada bagian atas tidak intensif (Ansori C, 2002)

\section{Anggota Tuf Formasi Waturanda (Tmwt)}

Formasi ini berada pada sebagian kecil Desa Kalidadap, tersusun oleh perselingan tuf kaca, tuf hablur, batupasir gampingan dan napal tufan; padat, berlapis baik setebal $2 \mathrm{~cm}$ s.d. $80 \mathrm{~cm}$; rekahan terisi kalsit. Tuf, terdiri dari felspar, kaca, kuarsa dan mineral bijih. Batupasir gampingan, tebal $4 \mathrm{~cm}$ s.d. $15 \mathrm{~m}$, mengandung foraminifera plangton yang menunjukkan umur N6 akhir - N8 awal (Miosen Awal). Lingkungan pengendapan batial atas, tebal satuan beberapa meter hingga $200 \mathrm{~m}$. Satuan menindih selaras Formasi Totogan dan merupakan bagian bawah Formasi Waturanda. (Condon, W. H.,, Pardyanto, L. Ketner, K. B. Amin, T. C. Gafoer, S. Samodra, 1996)

\section{Formasi Waturanda (Tmw)}

Formasi ini tersusun oleh breksi vulkanik serta batupasir dalam perulangan perlapisan yang tebal.Breksi umumnya tersusun olehfragmen andesitik dengan ukuran beragam dari kerikil hingga bongkah lebih dari 1 meter. Masa dasar berupa pasir kasar, struktur sedimen yang dijumpai berupa perlapisan bersusun normal, bersusun terbalik, dan laminasi sejajar. Formasi ini selaras di atas Formasi Totogan dan selaras ditindih Formasi Penosogan, diendapkan sebagai endapan turbidit, berumur Miosen Awal (N5 -N8).

\section{Formasi Penosogan (Tmp)}

Formasi ini terletak selaras di atas Formasi Waturanda, tersusun oleh perselingan batupasir, batulempung, tuf, napal dan kalkarenit; berlapis baik dengan tebal lapisan antara $5 \mathrm{~cm}$ s.d. $60 \mathrm{~cm}$, berwarna kelabu. Bagian bawah, berupa batupasir wacke; batupasir gampingan. Bagian atas, lebih gampingan dan berbutir lebih halus; terdiri terutama dari napal tufan dan tuf, serta sedikit kalkarenit (Asikin, S. Handoyo, A. Busono, H. Gafoer, 1992).

Anggota Breksi Formasi Halang (Tmpb) Formasi ini tersusun oleh breksi gunungapi dengan komponen basal dan sebagian 
andesit, masa dasar berupa batupasir tufan. Di beberapa tempat, terdapat sisipan batupasir dan lava basal. Secara mendatar litologi satuan ini berubah menjadi konglomerat yang berselingan dengan batupasir dan napal (Asikin, S., Handoyo, A. Busono, H. Gafoer, 1992).

\section{Formasi Peniron (Tpp)}

Horizon Breksi III, setempat mengandung sisa tumbuhan dan terkersikkan. Breksi aneka bahan komponen andesit piroksen, batu lempung dan batugamping, matrik batupasir lempungan dan tufan, bersisipkan batupasir, tuf dan napal. Merupakan endapan turbit yang diendapkan di bagian atas kipas bawah laut (Suharyanto, 1982 dalam (Asikin, S. Handoyo, A. Busono, H. Gafoer, 1992). Umur formasi diduga Pliosen (Suyanto F.X., 1975). Tebal satuan diduga $700 \mathrm{~m}$, tidak selaras di atas Formasi Halang dan ditindih secara tidak selaras di bawah oleh batuan gunungapi Sumbing Muda. Ke arah utara dikorelasikan dengan anggota breksi Formasi Tapak (Tptb). Harloff (1933 dalam (Asikin, S. Handoyo, A. Busono, H. Gafoer, 1992) menamakan "derde breccie horizon".

\section{Intrusi Diabas (Tmd)}

Diabas dijumpai sebagai batuan beku intrusif yang mengintrusi Formasi Totogan. Pada beberapa bagian didapatkan aliran lava berstruktur bantal, namun sifatnya lebih andesitik dengan tekstur lebih kasar dibandingkan lava bantal pada komplek mélange. Kelompok batuan ini mempunyai afinitas tholeit busur kepulauan yang diduga sebagai hasil vulkanisme bawah laut. Menurut Soeria-Atmadja dkk, (1990) berdasarkan pentarikhan radiometrik K-Ar, diabas Gunung Parang berumur 26 Ma s.d. $39 \mathrm{Ma}$ atau sekitar Eosen -sampai dengan Oligosen yang identik dengan kisaran umur Formasi Karangsambung-Formasi Totogan.

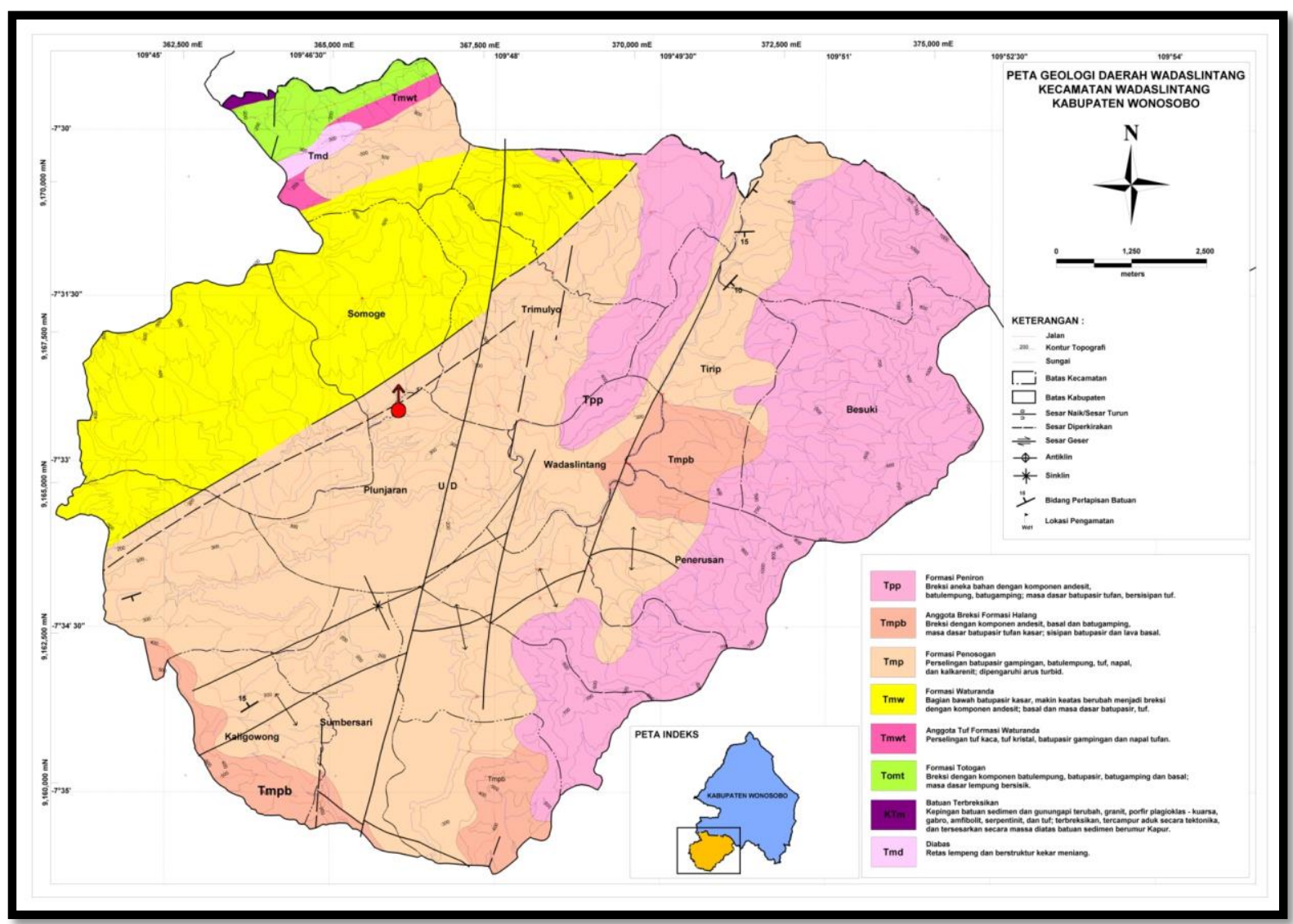

Gambar 1. Peta Geologi Kecamatan Wadaslintang 


\section{METODE PENELITIAN}

Penelitian lapangan dilakukan melalui kegiatan survei pada seluruh wilayah melalui lintasan jalan dan sungai. Pemilihan lintasan berdasarkan pendekatan terhadap peta geologi yang memungkinkan terjadinya proses mineralisasi terutama pada formasi batuan yang bersifat vulkanik dan sekitar tubuh intrusi. Untuk dapat mengetahui kualitas mineral dan batuan yang ada, maka dilakukan analisis kimia, petrografi, difraksi sinar X (XRD), berat jenis, kuat tekan, daya serap terhadap air, ketahanan terhadap pelapukan dan keausan.

Sedangkan untuk mengetahui ancaman bencana dilakukan pengamatan lokasilokasi longsor, kemiringan lahan, penggunaan lahan, pengukuran unsur struktur dan pengambilan conto tanah. Metode analisis menggunakan Analytical Hierarchy Process (AHP), yang dikembangkan oleh (Saaty T.L., 1980) yang mencoba menguraikan masalah multi faktor atau multi kriteria yang kompleks menjadi suatu hirarki.

\section{HASIL DAN PEMBAHASAN \\ Potensi Mineral Bukan Logam dan Batuan}

Sumber daya mineral yang terdapat di daerah penelitian mencakup mineral bukan logam (kaolin) dan batuan seperti (batu tempel, diabas, andesit, batu mulia dan tanah merah). Sedangkan peta sebarannya dapat dilihat pada Gambar 9.

\section{Kaolin}

Kaolin dijumpai di Desa Kalidadap merupakan zone altrasi, berasosiasi dengan mineral sulfida pirit, kalsedon dan urat silika pada tubuh intrusi diabas yang mengintrusi lempung Formasi Totogan. Terbentuk akibat proses alterasi hidrotermal pada kondisi sulfida rendah di zone atas. Sebaran kaolin 17,26 ha, dengan sumber daya hipotetik sekitar $8.630 .000 \mathrm{~m}^{3}$.

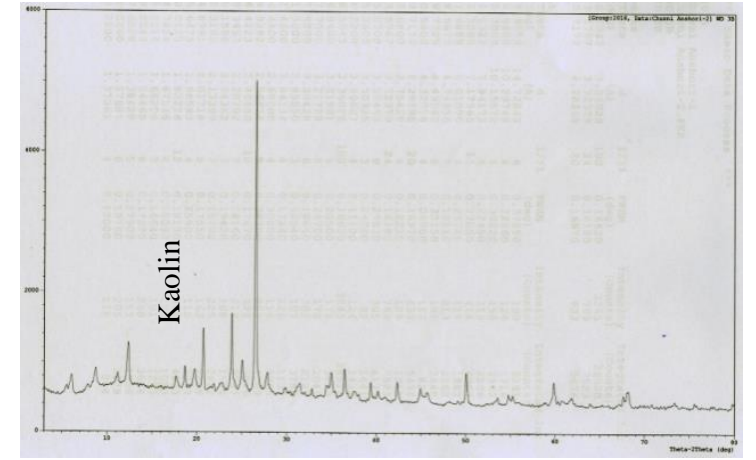

Gambar 2. Pola XRD lempung kaolin

Analisis kimia menunjukkan kandungan $\mathrm{SiO}_{2}$ 53\% s.d. 56,99\%, $\mathrm{CaO} 0,26 \%$ s.d. $3 \%, \mathrm{Al}_{2} \mathrm{O}_{3} 16 \%$ s.d. $22,02 \%, \mathrm{Fe}_{2} \mathrm{O}_{3} 12,72 \%$ s.d. $8,67 \%$ (Tabel 1). Persyaratan untuk industri kertas, kandungan $\mathrm{Fe}_{2} \mathrm{O}_{3}<0,92 \%$, $\mathrm{CaO} 0,05 \%, \mathrm{Al}_{2} \mathrm{O}_{3} 37,3 \%$. Sedangkan jika digunakan untuk industri keramik komposisi $\mathrm{Fe}_{2} \mathrm{O}_{3}<1 \%, \mathrm{TiO}_{2}<0,7 \%, \mathrm{CaO}<$ $0,8 \%, \quad \mathrm{SO}_{3}<0,4 \% \quad$ (Suhala, 1997). Kandungan $\mathrm{Fe}_{2} \mathrm{O}_{3}$ dan $\mathrm{CaO}$ yang tinggi, serta $\mathrm{Al}_{2} \mathrm{O}_{3}$ yang sangat rendah, menjadikan kualitasnya kurang baik jika dimanfaatkan untuk industri kertas maupun keramik. Kandungan $\mathrm{Fe}_{2} \mathrm{O}_{3}$ tinggi mengindikasikan adanya mineral pengotor, misalnya pirit yang mempunyai kandungan Fe tinggi. Asosiasi mineral pengotor lain dapat berupa pasir kuarsa, oksida besi, maupun oksida titan. Agar kaolin dapat dimanfaatkan dalam industri perlu proses pengolahan lebih lanjut.

Tabel 1. Hasil analisis kimia kaolin

\begin{tabular}{lrr}
\hline \multirow{2}{*}{ Parameter } & \multicolumn{2}{c}{ Conto Kaolin(\%) } \\
\cline { 2 - 3 } & WD 3A & WD 3C \\
\hline $\mathrm{SiO}_{2}$ & 53,64 & 56,99 \\
\hline $\mathrm{Al}_{2} \mathrm{O}_{3}$ & 16,00 & 22,02 \\
\hline $\mathrm{CaO}$ & 3,06 & 0,26 \\
\hline $\mathrm{MgO}$ & 2,87 & 2,09 \\
\hline $\mathrm{Na}_{2} \mathrm{O}$ & 4,86 & 2,31 \\
\hline $\mathrm{Fe}_{2} \mathrm{O}_{3}$ & 12,72 & 8,79 \\
\hline
\end{tabular}

\section{Diabas}

Diabas ditemukan di Desa Kalidadap berupa batuan beku intrusif dangkal dengan tekstur diabasik/ofitik (Gambar 6) yang terlihat cukup jelas secara megaskopis dan mikroskopis. Komposisi mineralnya terdiri dari plagioklas, piroksen, dan mineral opak. Selain itu berdasarkan 
pengamatan mikroskopis, batuan ini memiliki tekstur aliran, intergranular dan inequigranular. Sebaran diabas memanjang ke arah barat hingga wilayah Kecamatan Sadang, Kabupaten Kebumen. Luas sebaran mencapai 41,84 ha, dengan ketebalan batuan 2,0 m maka sumberdaya hipotetik diabas diperkirakan mencapai 8.368.000 $\mathrm{m}^{3}$. Berdasarkan hasil analisis; kuat tekan rata-rata $721,7 \mathrm{~kg} / \mathrm{cm}^{2}$, BJ 2,77 $\mathrm{gr} / \mathrm{cm}^{3}$ dan porositas $7,75 \%$ (Tabel 2) sehingga diabas dapat digunakan untuk pondasi bangunan ringan, batu tonggok tepi jalan, penutup trotoar maupun paving block.

\section{Kalkarenit}

Kalkarenit dijumpai di Dukuh Pacekelan dan Kemejing, berwarna kuning muda, berlapis-lapis dengan ketebalan lapisan antara $5 \mathrm{~cm}$ s.d. $10 \mathrm{~cm}$. Jika digali maka bisa mendapatkan lapisan batuan yang lebar yang dapat digunakan untuk batu tempel. Sebaran kalkarenit meluas hingga 22,51 ha sehingga dengan asumsi ketebalan dapat ditambang setebal $1 \mathrm{~m}$, maka sumberdaya hipotetik kalkarenit mencapai 2.251.000 $\mathrm{m}^{3}$. Berdasarkan analisis petrografi termasuk batugamping grain stone (Gambar 4) sedangkan analisis kuat tekan mencapai $666,9 \mathrm{~kg} / \mathrm{cm}^{2}$ dengan BJ $2,519 \mathrm{gr} / \mathrm{cm}^{3}$ dan porositas batuan $3,755 \%$ (Tabel 2) yang dapat digunakan sebagai batu hias dan paving block.

\section{Breksi Andesit}

Breksi andesit dijumpai di daerah penelitian dalam areal yang luas hingga 1.440,6 ha yang termasuk dalam Formasi Waturanda (Tmw), anggota breksi Formasi Halang (Tmpb) dan Formasi Peniron (Tpp). Breksi tersusun oleh fragmen andesit dengan ukuran $5 \mathrm{~cm}$ s.d. $40 \mathrm{~cm}$, kemas terbuka dan sortasi jelek, komponen fragmen $>20$ $\mathrm{cm}$ sekitar $30 \%$ sehingga sumberdaya hipotetik fragmen andesit mencapai sekitar $44.504 .400 \mathrm{~m}^{2}$. Analisis petrografi fragmen breksi termasuk andesit dengan kandungan feldspar tinggi (Gambar 8). Berdasarkan hasil analisis, sifat fisiknya mempunyai kuat tekan rata-rata $1.251,9$ $\mathrm{kg} / \mathrm{cm}^{2}$, sehingga fragmen andesit dapat digunakan untuk pondasi bangunan bertingkat sedang (Tabel 2). Matriks breksi bisa digunakan sebagai pasir bangunan serta material urug.

\section{Tanah Merah}

Tanah merah merupakan hasil pelapukan dari breksi serta tuff pada Formasi Peniron dan Fomasi Halang. Sebaran tanah merah ini banyak terdapat di bagian tengah wilayah penelitian di sekitar Trimulyo. Tanah urug biasanya dipersyaratkan bebas dari bahan organik dan merupakan tanah merah podzolik atau latosol coklat kekuningan. Menurut pedoman, kualitas tanah urug bukan tanah organik yang berwarna hitam atau tanah liat yang susah dikeringkan, sirtu termasuk salah satu jenis tanah urug yang sering dipakai. Tanah padas juga sering digunakan sebagai tanah urug karena tidak lengket dan licin jika basah (hujan), tidak pecah-pecah jika kering. Tanah jenis ini sangat baik digunakan untuk urugan karena tanah langsung padat dan tidak mudah bergeser. Sebaran tanah merah ini mencapai luas sekitar 55,06 ha, sehingga dengan asumsi ketebalan tanah mencapai $2 \mathrm{~m}$, maka sumber daya hipotetiknya sebesar $11.012 .000 \mathrm{~m}^{3}$.

\section{Batupasir}

Batupasir padat dan kompak banyak dijumpai di bagian bawah Formasi Waturanda yang tersebar berarah barattimur dengan arah sekitar $\mathrm{N} 79^{\circ} \mathrm{E} / 19^{\circ}$ mulai Desa Lancar, Desa Somagede, Desa Trimuyo dan Desa Ngalian. Ketebaan lapisan sekitar $5 \mathrm{~m}$ s.d. $10 \mathrm{~m}$ yang berada di bawah soil merah dengan ketebalan $2 \mathrm{~m}$ s.d. $3 \mathrm{~m}$. warna abu-abu kehijauan, sortasi baik, kemas tertutup, tersusun oleh fragmen batupasir, batulempung, batuan beku dalam masa dasar pasir kasar berupa feldspar, kuarsa dan piroksen dengan semen silika. Berdasarkan analisis petrografi termasuk dalam lithic wacke. Di lapangan potensi batupasir ini digunakan sebagai pondasi rumah. Berdasarkan analisis kuat tekan sekitar $137,4 \mathrm{~kg} / \mathrm{cm}^{2}$ s.d. $125,35 \mathrm{~kg} / \mathrm{cm}^{2}$ dengan porositas antara $17 \%$ s.d. $20 \%$ serta BJ sekitar $2,5 \mathrm{gr} / \mathrm{cm}^{3}$ (Tabel 2), sehingga tidak memenuhi syarat untuk pondasi bangunan maupun batu hias 
namun dapat digunakan sebagai sumber pasir bangunan setelah melalui proses penghancuran (crushing) sehingga terurai menjadi partikel kecil. Sebaran potensi batupasir sekitar 737,6 ha, sehingga jika dengan asumsi ketebalan $5 \mathrm{~m}$, maka besarnya sumber daya hipotetiknya mencapai $368.800 .000 \mathrm{~m}^{3}$.

\section{Batumulia}

Potensi batumulia di daerah penelitian terdapat di hulu Sungai Luk Ulo sekitar Dukuh Melokan, Kalidadap. Batu mulia yang ditemukan dalam bentuk kerikil bongkah di sepanjang sungai. Jenis batu

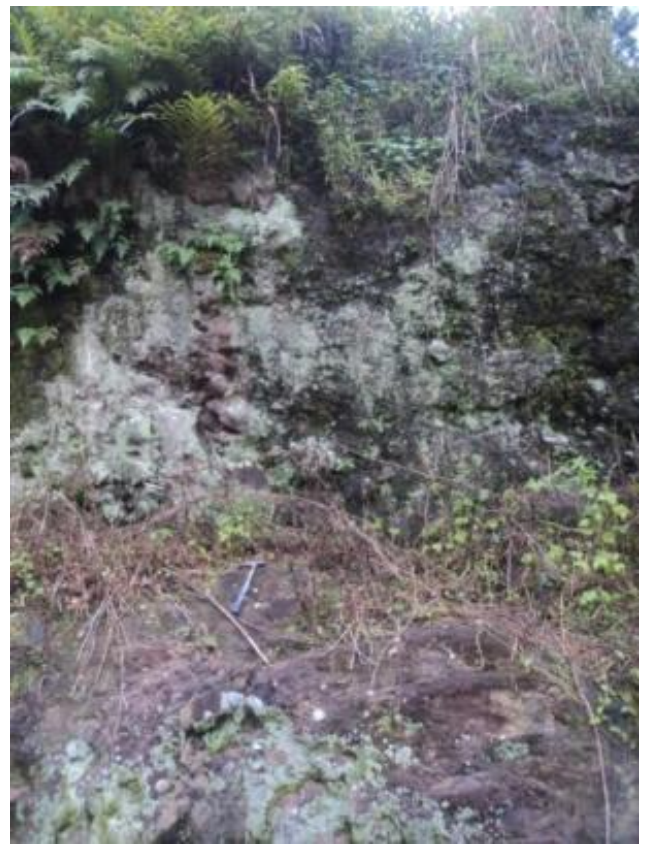

mulia yang ditemukan antara lain berupa agate, kalsedon, badar besi merah (red magnetite), jasper, batu bergambar dan panca warna. Sebaran batu mulia dijumpai secara sporadis dan banyak diburu para kolektor batuan dari sekitar Wonosobo. Ukuran bongkah bervariasi, umumnya berukuran kerikil sehingga pemanfaatannya bisa langsung dibentuk untuk menjadi cincin. Sebaran batu mulia hanya berada di sekitar aliran Sungai Luk Ulo yang diperkirakan sebagai hasil proses pelapukan batuan kompleks melange Luk Ulo yang berada di bagian utara wilayah penelitian di Kecamatan Kaliwiro.
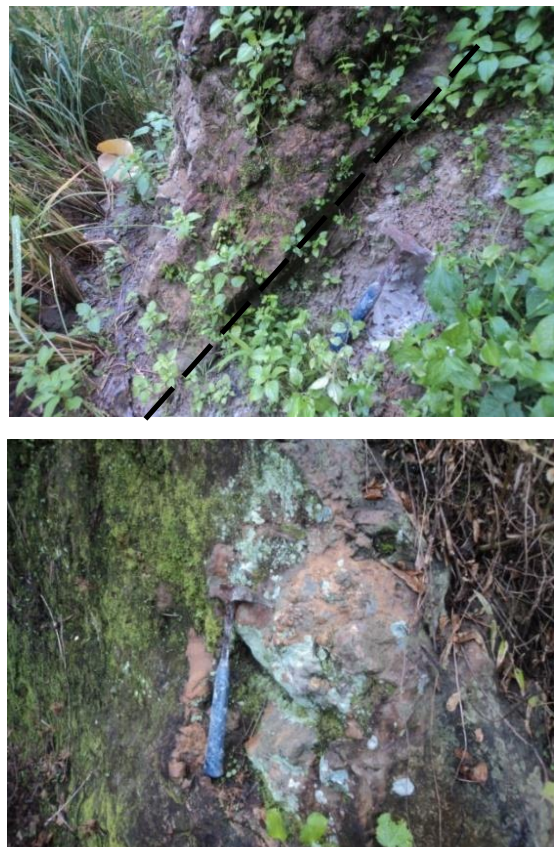

Gambar 3. Intrusi diabas serta lempung yang teruban menjaaı kaoın disertai pembentukan jasperoid

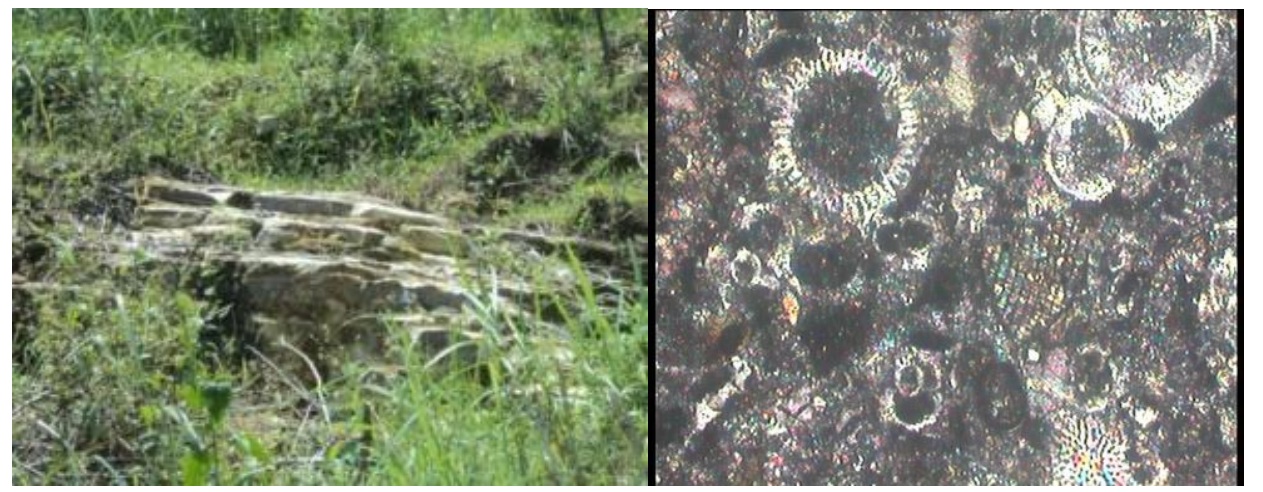

Gambar 4. Singkapan kalkarenit dan foto mikroskopnya yang menunjukkan adanya butiran mineral dan fosil termasuk grainstone 


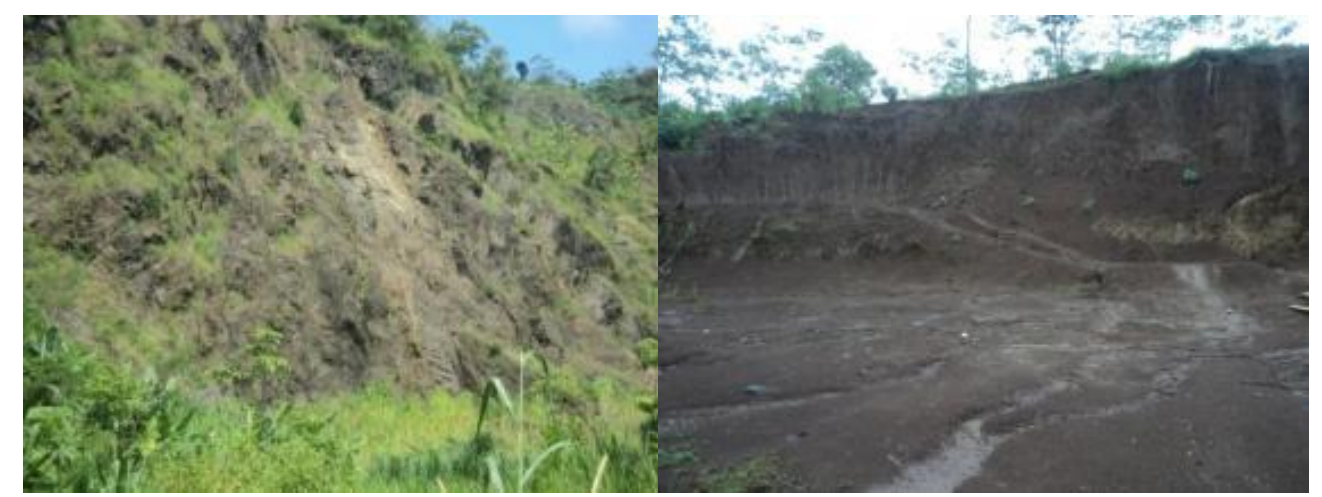

Gambar 5. Bekas quarry breksi andesit dan tanah merah

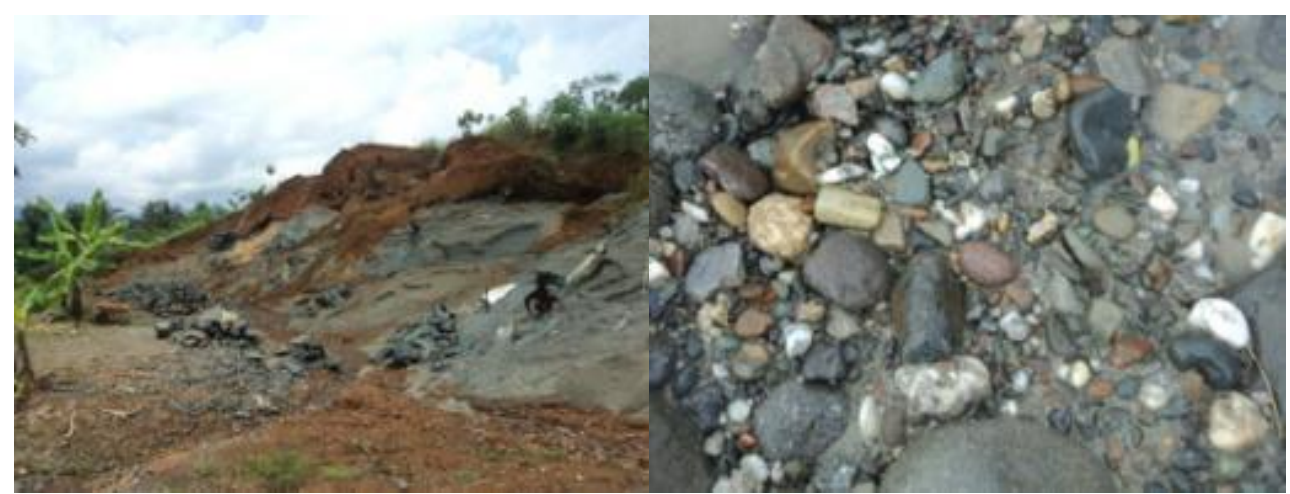

Gambar 6. Aktivitas penambangan batupasir Formasi Waturanda serta fragmen batu mulia pada endapan sungai

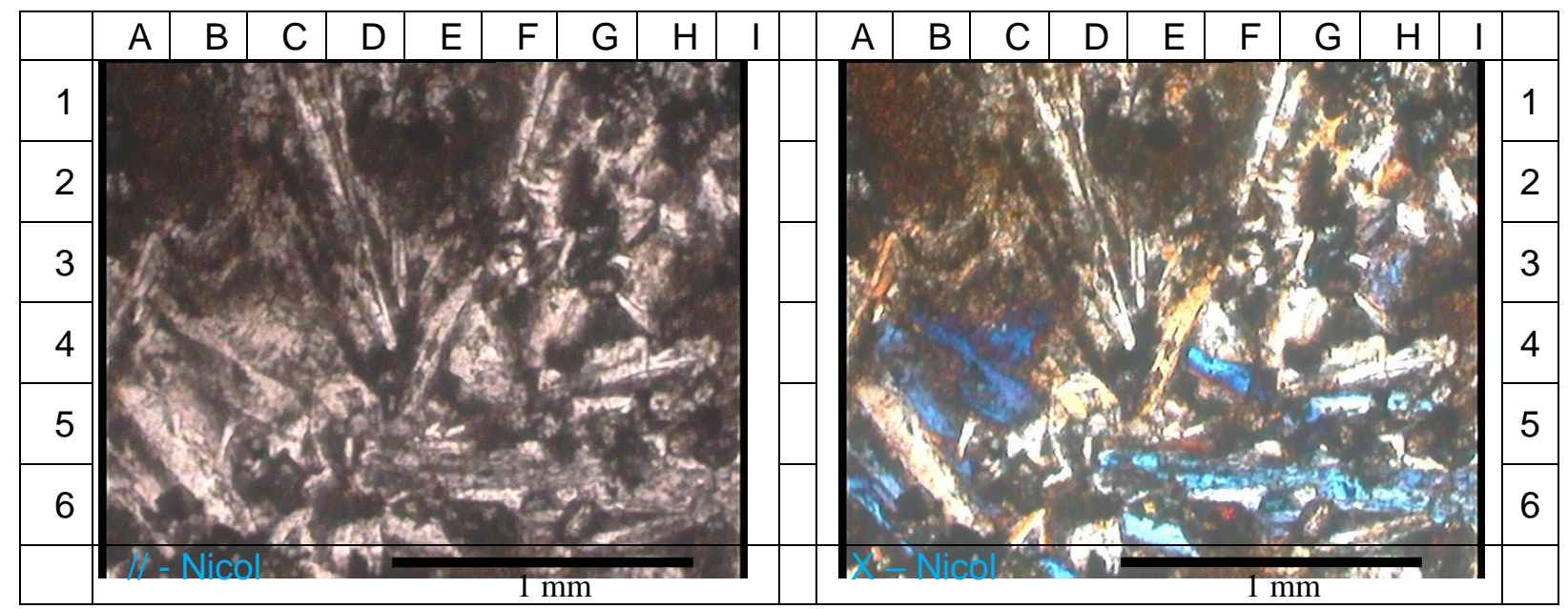

Gambar 7. Sayatan tipis diabas dari Desa Kalidadap yang menunjukkan tekstur diabasik/ofitik 


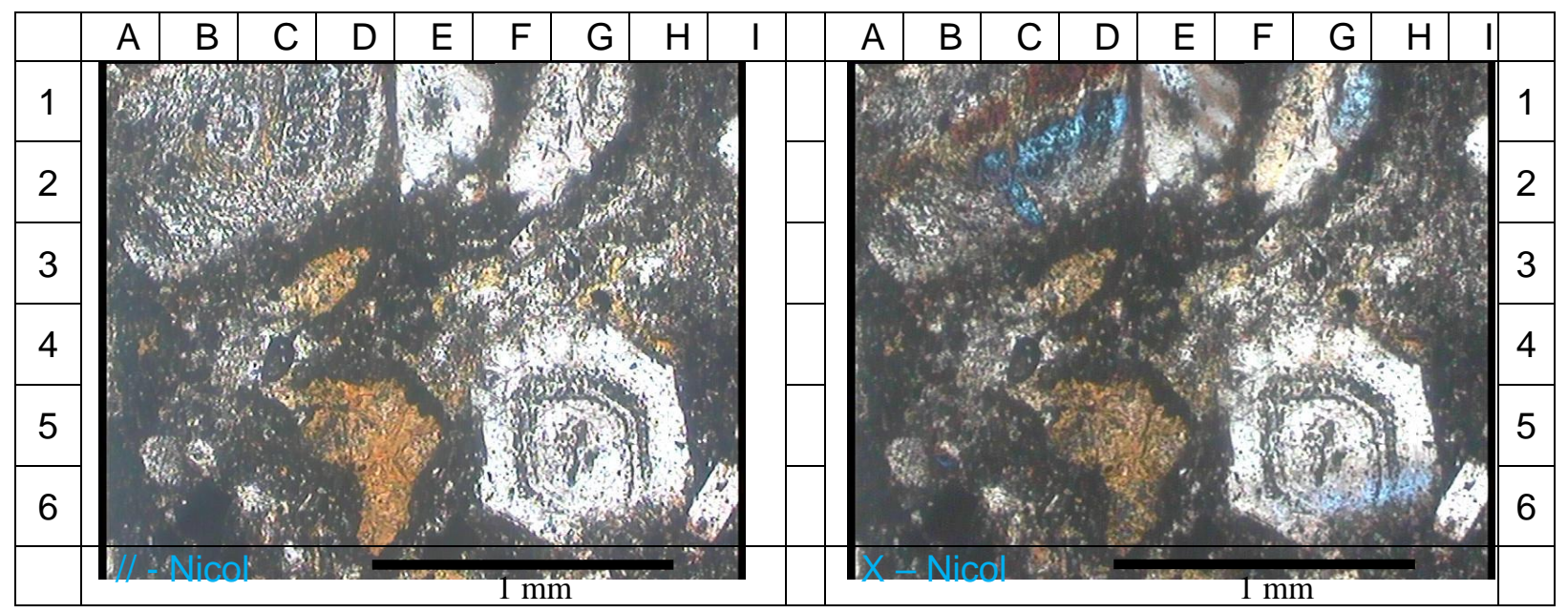

Gambar 8. Foto mikroskop fragmen breksi andesit dengan struktur zoning

Tabel 2. Hasil analisis sifat fisik batuan

\begin{tabular}{crrrrrrr}
\hline \multirow{2}{*}{ No } & \multirow{2}{*}{ Lokasi } & \multicolumn{2}{c}{ Kuat tekan $\left(\mathrm{kg} / \mathrm{cm}^{2}\right)$} & \multicolumn{2}{c}{$\mathrm{Bj}\left(\mathrm{gr} / \mathrm{cm}^{3}\right)$} & \multicolumn{2}{c}{ Porositas $(\%)$} \\
\cline { 3 - 8 } & terukur & rata-rata & terukur & rata-rata & terukur & rata-rata \\
\hline 1 & WD-3 & 717 & 719,35 & 2,782 & 2,7785 & 7,22 & 7,75 \\
\hline & Diabas & 721,7 & & 2,775 & & 8,28 & \\
\hline 2 & WD-7 & 652,1 & 659,5 & 2,535 & 2,527 & 3,93 & 3,755 \\
\hline & Kalkarenit & 666,9 & & 2,519 & & 3,58 & \\
\hline 3 & WD-11 & 143,5 & 137,4 & 2,66 & 2,65 & 20,52 & 20,055 \\
\hline & Batupasir & 131,3 & & 2,64 & & 19,59 & \\
\hline 4 & WD-12 & 133,5 & 130,25 & 2,593 & 2,587 & 19,03 & 18,745 \\
\hline & Batupasir & 127 & & 2,581 & & 18,46 & \\
\hline 5 & WD-13 & 122 & 125,35 & 2,544 & 2,54 & 16,42 & 17,085 \\
\hline & Batupasir & 128,7 & & 2,536 & & 17,75 & \\
\hline 6 & WD-30 & $1.331,1$ & 1291,5 & 2,53 & 2,55 & 6,08 & 6,165 \\
\hline & Andesit & $1.251,9$ & & 2,57 & & 6,25 & \\
\hline
\end{tabular}

Tabel 3. Syarat Mutu Batu Alam untuk Bahan Bangunan (Anonim, 1989)

\begin{tabular}{|c|c|c|c|c|c|c|}
\hline \multirow{3}{*}{ Sifat - sifat } & \multicolumn{6}{|c|}{ Batu Alam untuk } \\
\hline & \multicolumn{3}{|c|}{ Pondasi Bangunan } & \multirow{2}{*}{$\begin{array}{c}\text { Tonggak } \\
\text { Batu Tepi } \\
\text { Jalan }\end{array}$} & \multirow{2}{*}{$\begin{array}{l}\text { Penutup } \\
\text { Lantai } \\
\text { Trotoar }\end{array}$} & \multirow{2}{*}{$\begin{array}{l}\text { Batu } \\
\text { Hias/ } \\
\text { Tempel }\end{array}$} \\
\hline & Berat & Sedang & Ringan & & & \\
\hline Kuat tekan minimum, $\mathrm{kg} / \mathrm{cm}^{2}$ & 1.500 & 1.000 & 800 & 500 & 600 & 200 \\
\hline $\begin{array}{l}\text { Ketahanan geser Los Angeles, } \\
\text { bagian tembus } 1,7 \mathrm{~mm} \text { (\% mak) }\end{array}$ & 27 & 40 & 50 & - & - & - \\
\hline $\begin{array}{l}\text { Ketahanan aus gesekan dengan } \\
\text { Bauschinger, mm/menit, mak }\end{array}$ & - & - & - & - & 0,16 & - \\
\hline Penyerapan air maksimum, \% & 5 & 5 & 8 & 5 & 5 & $\begin{array}{c}5^{*} \\
12^{* *}\end{array}$ \\
\hline $\begin{array}{l}\text { Kekekalan bentuk dengan } \mathrm{Na}_{2} \mathrm{SO}_{4} \\
\text { bagian: }\end{array}$ & & & & & & \\
\hline $\begin{array}{l}\text { a. Hancur maksimum \% } \\
\text { b. Retak/Pecah/Cacat }\end{array}$ & 12 & 12 & 12 & 12 & 12 & 12 \\
\hline
\end{tabular}




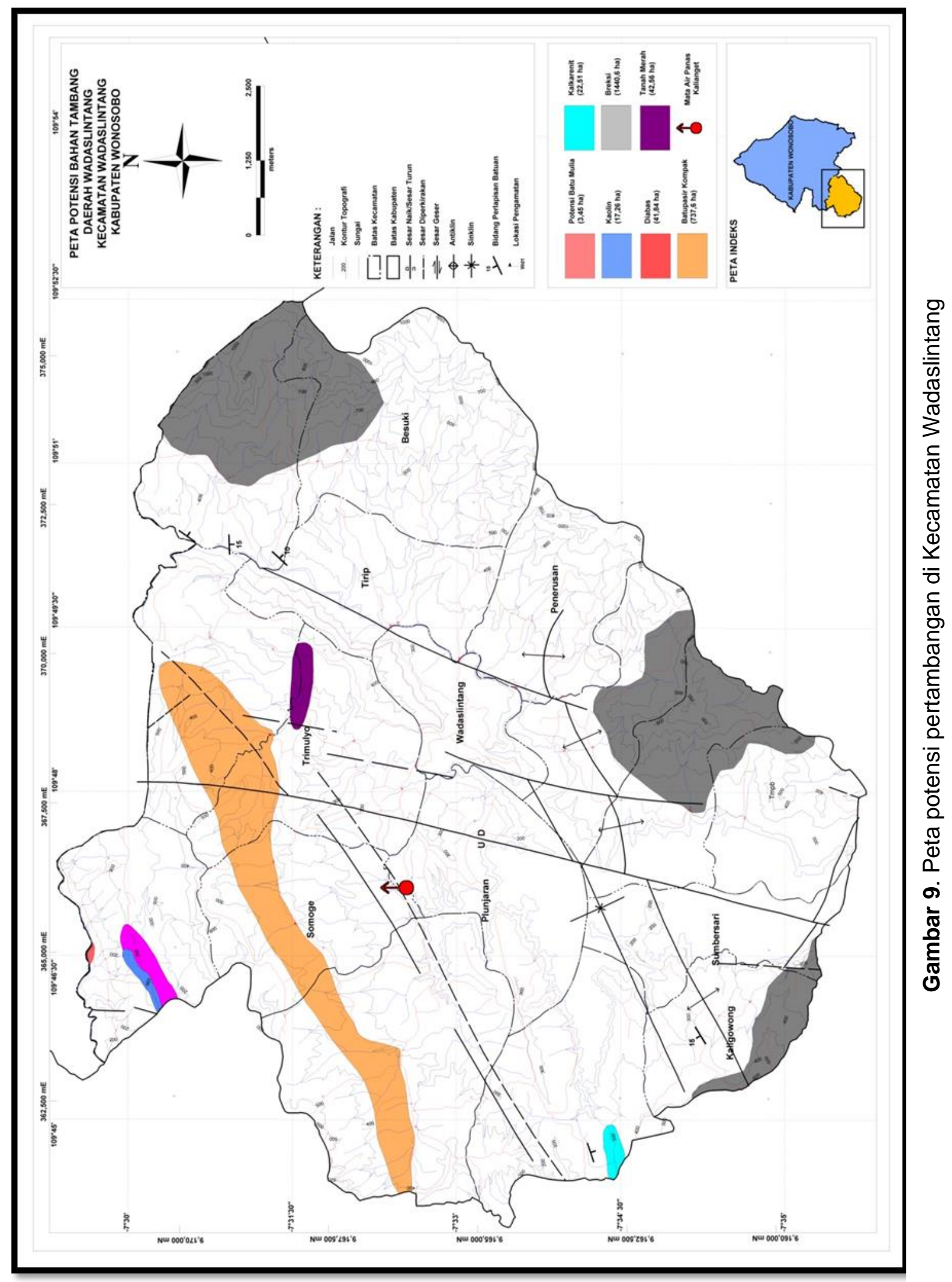


Ancaman Bencana Longsor

Komponen ancaman disusun berdasarkan parameter intensitas dan probabilitas kejadian. Indeks Ancaman Bencana Longsor di Kecamatan Wadaslintang disusun menggunakan metode Analytical Hierarchy Process (AHP) yaitu pengambilan keputusan berdasarkan permasalahan multi faktor atau multi kriteria yang kompleks menjadi suatu hirarki. Kriteria yang digunakan dalam penelitian ini yaitu, kemiringan lereng, geologi, karakteristik tanah, dan penggunaan lahan.

Indeks Ancaman Bencana disusun berdasarkan dua komponen utama, yaitu kemungkinan terjadi suatu ancaman dan besaran dampak yang pernah tercatat untuk bencana yang terjadi tersebut. Tabel 4 merupakan persentase pengaruh dari tiap-tiap faktor dalam mempengaruhi (pengontrol) terjadinya longsor di Kecamatan Wadaslintang dengan menggunakan metode analytic hierarchy processes. Kemiringan lereng pada penelitian ini memberikan pengaruh paling besar, yaitu sekitar $60 \%$, sedangkan faktor geologi memiliki pengaruh sekitar $21 \%$. Asumsi yang digunakan untuk faktor geologi ini didasarkan bahwa lithologi yang ada di Kecamatan Wadaslintang ini ratarata karakteristiknya sama. Tidak ada litologi yang sangat dominan dalam mempengaruhi terjadinya longsor di daerah ini. Faktor karakteristik tanah memiliki pengaruh yang kecil, hanya sekitar $13 \%$. Hal ini diakibatkan pada perhitungan factor of safety di Kecamatan Wadaslintang ini dihasilkan nilai dengan rentan yang relatif pendek sehingga pengklasifikasian untuk karakteristik ini masih pada tipe nilai yang hampir sama. Pada faktor jenis penggunaan lahan memiliki pengaruh sangat kecil, hanya sekitar $6 \%$. Hal ini dinilai sangat kondisional di lapangan. merupakan peta ancaman longsor di Kecamatan Wadaslintang ditampilkan pada Gambar 9.

Pada lahan terbangun (pemukiman) konsentrasi banyak berada di daerah dengan topografi datar sampai landai.
Meskipun banyak pemukiman yang berada di daerah dengan topografi berbukit. Namun skala peta yang digunakan dalam pemetaan jenis penggunaan lahan ini tidak bisa merekam dari kedetailan jenis penggunaan lahan, sebagian besar tertutup oleh adanya vegetasi. Tipe pemukiman yang ada di Kecamatan Wadasalintang ini juga memiliki tipe lahan pemukiman pedesaan, dimana pada lahan terbangun masih memiliki halaman yang bervegetasi dari sedang hingga rapat. Hasil yang diperoleh, ancaman longsor paling tinggi berada di desa-desa; Medono, Gumelar, Mergolangu, Giyambong, Cepedak, Trimulyo, Sumberrejo, Erorejo, Kumenjing, dan Tirip. Sedangkan ancaman longsor menengah terjadi di sekitar desadesa; Somoge, Kaligowong, dan Lancar. Sebagian dari lokasi penelitian ini memiliki jenis penggunaan lahan berupa tubuh air (Waduk Wadaslintang). Sehingga tubuh air ini tidak masuk dalam klasifikasi meskipun pada perhitungannya tetap dilakukan mengingat penelitian ini bersifat spasial.

\section{Penataan Wilayah Tambang}

Wilayah Pertambangan (WP) terdiri atas WUP, WPR dan/atau Wilayah Pencadangan Negara (WPN). WUP terdiri atas WUP mineral radioaktif, mineral logam, batubara, mineral bukan logam, dan batuan. Penyusunan rencana WUP berdasarkan PP Nomor 22 Tahun 2010 harus memenuhi kriteria: memiliki formasi batuan pembawa, baik di darat maupun lepas pantai; memiliki singkapan geologi untuk mineral, batubara dan batuan; memiliki potensi sumber daya mineral atau batubara; memiliki 1 atau lebih jenis mineral termasuk mineral ikutannya dan/atau batubara; tidak tumpang tindih dengan WPR dan/atau WPN; merupakan wilayah yang dapat dimanfaatkan untuk kegiatan pertambangan secara berkelanjutan; merupakan kawasan peruntukan pertambangan sesuai rencana tata ruang. Mengacu pada UU no 4/2009 dan PP no 23/2010 tentang Pelaksanaan Kegiatan Usaha Pertambangan Mineral dan Batubara, Izin Usaha Pertambangan (IUP) dan Izin Pertambangan Rakyat (IPR) 
mempunyai batasan luasan seperti terlihat padaTabel 4.

Dalam PERDA No 2 Tahun 2011 tentang RTRW Kabupaten Wonosobo 2011-2031 pasal 39 menyatakan bahwa Kawasan Peruntukan Pertambangan mencakup kawasan pertambangan mineral bukan logam dan batuan serta kawasan pertambangan panas bumi. Kawasan pertambangan bukan logam dan batuan mencakup luasan sekitar 194 ha di kecamatan kecamatan Watumalang, Mojotengah, Garung, Sukaharjo, Kalibawang, Kertek dan Wadaslintang. Andesit berada di kecamatan-kecamatan Watumalang, Mojotengah dan Garung. Batu belah di Sokoharjo dan Watumalang, sirtu berada di Kertek, Wadaslintang dan bentonit di Kecamatan Kalibawang. Di Kecamatan Wadaslintang peruntukan wilayah tambangnya hanya berupa sirtu yang berada di sekitar Sungai Luk Ulo. Di lokasi ini tidak termasuk kawasan lindung, namun peruntukannya lebih banyak sebagai kawasan hutan produksi, hutan rakyat, pertanian, hortikultura, perkebunan, peternakan dan perikanan. Pada sisi lain Kecamatan ini juga merupakan kawasan resiko longsor. Keberadaan sebaran potensi bahan tambang dimungkinkan untuk dijadikan sebagai WUP atapun WPR namun harus mempertimbangkan keberadaan ancaman longsor. Dalam penyusunan Rencana Detail Tata Ruang Kota (RDTRK) jika akan memperluas wilayah pertambangan perlu dilakukan proses tumpang susun antara sebaran potensi mineral bukan logam dan batuan dengan sebaran ancaman bencana tanah longsor. Wilayah pertambangan yang disarankan adalah pada areal yang mempunyai potensi bahan tambang dengan luasan sesuai PP no 23/2010 namun berada pada areal dengan ancaman bencana longsor rendah hingga sedang. Pada areal dengan ancaman bencana longsor tinggi tidak diperbolehkan untuk melakukan penambangan karena sangat potensial terhadap terjadinya longsor.

Potensi batu mulia seluas 3,45 ha yang semuanya berada di Sungai Luk Ulo bisa dimanfaatkan, karena berada pada areal dengan tingkat ancaman bencana rendah dan sedang. Mineral bukan logam berupa Kaolin dengan potensi seluas 17,26 ha merupakan areal tambang yang mudah longsor. Wilayah Pertambangan yang disarankan berada pada areal dengan ancaman bencana longsor rendah sampai sedang seluas 14,76 ha. Diabas yang merupakan batuan beku dan memenuhi syarat sebagai bahan pondasi bangunan dijumpai pada areal 42,84 ha, namun yang layak untuk ditambang berada pada areal 35,29 ha. Breksi yang merupakan areal dengan potensi terluas 1.440,6 ha, sebagian besar berada pada lokasi dengan ancaman bencana tinggi sehingga luas areal yang bisa dijadikan wilayah pertambangan adalah 838,92 ha. Luas potensi tanah merah 42,56 ha dengan luas wilayah tambang yang disarankan hanya 32,29 ha, luas potensi batupasir 737,6 ha dengan luas areal yang disarankan 523,4 ha. 
Tabel 4. Perhitungan ancaman longsor

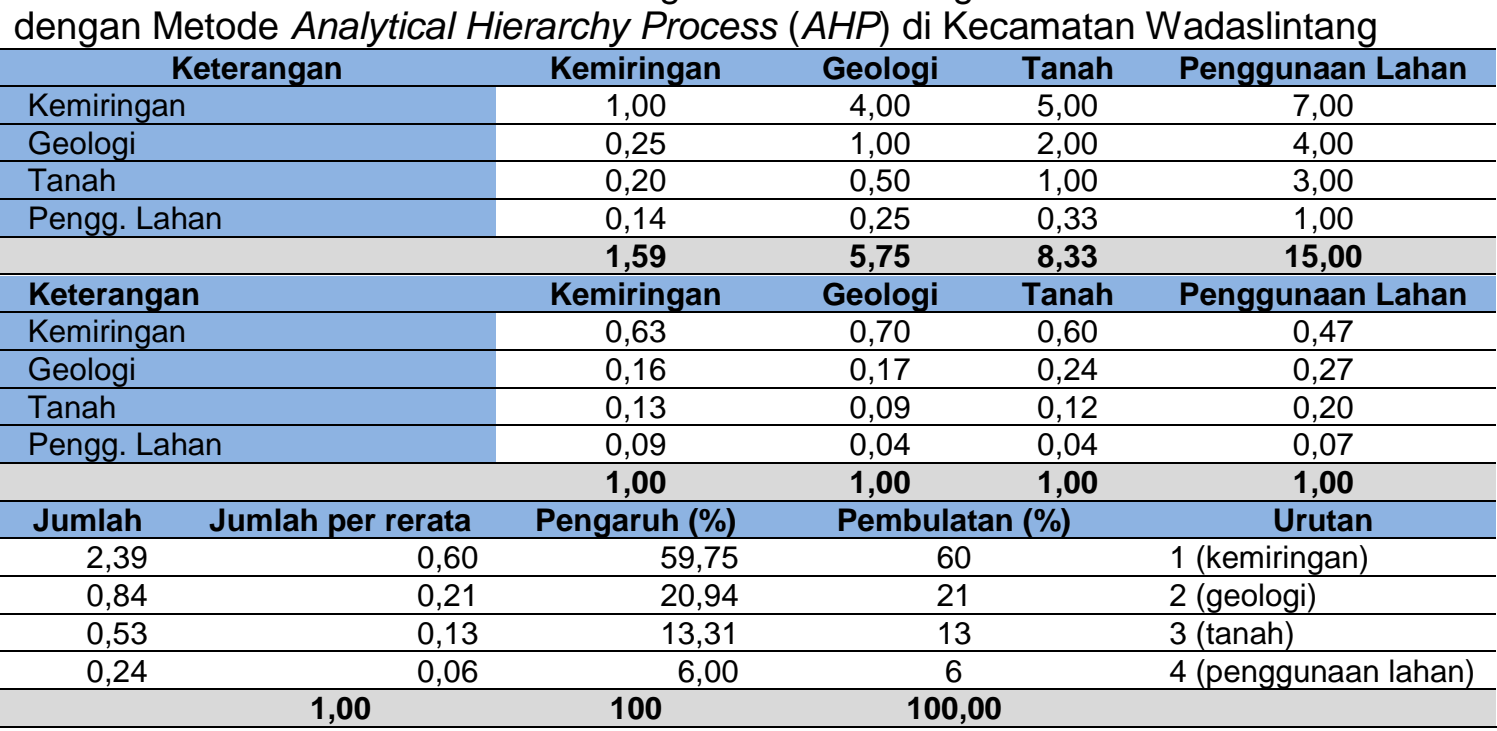

Tabel 5. Batasan Wilayah Pertambangan (Ansori C; Hastria, 2012)

\begin{tabular}{|c|c|c|c|c|c|}
\hline \multirow{6}{*}{ IUP } & \multirow{2}{*}{ Komoditas } & \multicolumn{2}{|c|}{ Eksplorasi } & \multicolumn{2}{|c|}{ Operasi Produksi } \\
\hline & & Minimal (ha) & Maksimal (ha) & Minimal (ha) & Maksimal (ha) \\
\hline & Logam & 5.000 & 10.000 & - & 5.000 \\
\hline & Batubara & 5.000 & 15.000 & - & 5.000 \\
\hline & Non Logam & 500 & 1000 & - & 20 \\
\hline & Batuan & 5 & 500 & - & 10 \\
\hline \multirow{4}{*}{ IPR } & Pemohon & & Eksplorasi & & Derasi Produksi \\
\hline & Perorangan & - & - & - & 1 \\
\hline & Kel. Masyarakat & - & - & - & 5 \\
\hline & Koperasi & - & - & - & 10 \\
\hline
\end{tabular}

Tabel 6. Luas wilayah pertambangan di daerah penelitian

\begin{tabular}{|c|c|c|c|c|c|}
\hline \multirow{2}{*}{$\begin{array}{c}\text { Komoditas } \\
\text { Tambang }\end{array}$} & \multirow{2}{*}{$\begin{array}{l}\text { Luas } \\
\text { Potensi } \\
\text { (ha) }\end{array}$} & \multicolumn{2}{|c|}{ Luas Potensi Pada Ancaman bencana } & \multirow{2}{*}{$\begin{array}{l}\text { Luas WP } \\
\text { (ha) }\end{array}$} & \multirow{2}{*}{$\begin{array}{c}\% \text { Pengurangan } \\
\text { Luas }\end{array}$} \\
\hline & & Rendah (ha) & Sedang (ha) & & \\
\hline Batu mulia & 3,45 & 3,23 & 0,22 & 3,45 & 0 \\
\hline Kaolin & 17,26 & 7,89 & 6,87 & 14,76 & 14,484 \\
\hline Diabas & 41,84 & 22,66 & 12,63 & 35,29 & 15,655 \\
\hline Kalkarenit & 22,51 & 0,78 & 5,1 & 5,88 & 73,878 \\
\hline Breksi & 1440,6 & 415,52 & 423,4 & 838,92 & 41,766 \\
\hline Tanah Merah & 42,56 & 26,43 & 5,86 & 32,29 & 24,131 \\
\hline Batu pasir & 737,6 & 68,14 & 455,26 & 523,4 & 29,040 \\
\hline
\end{tabular}



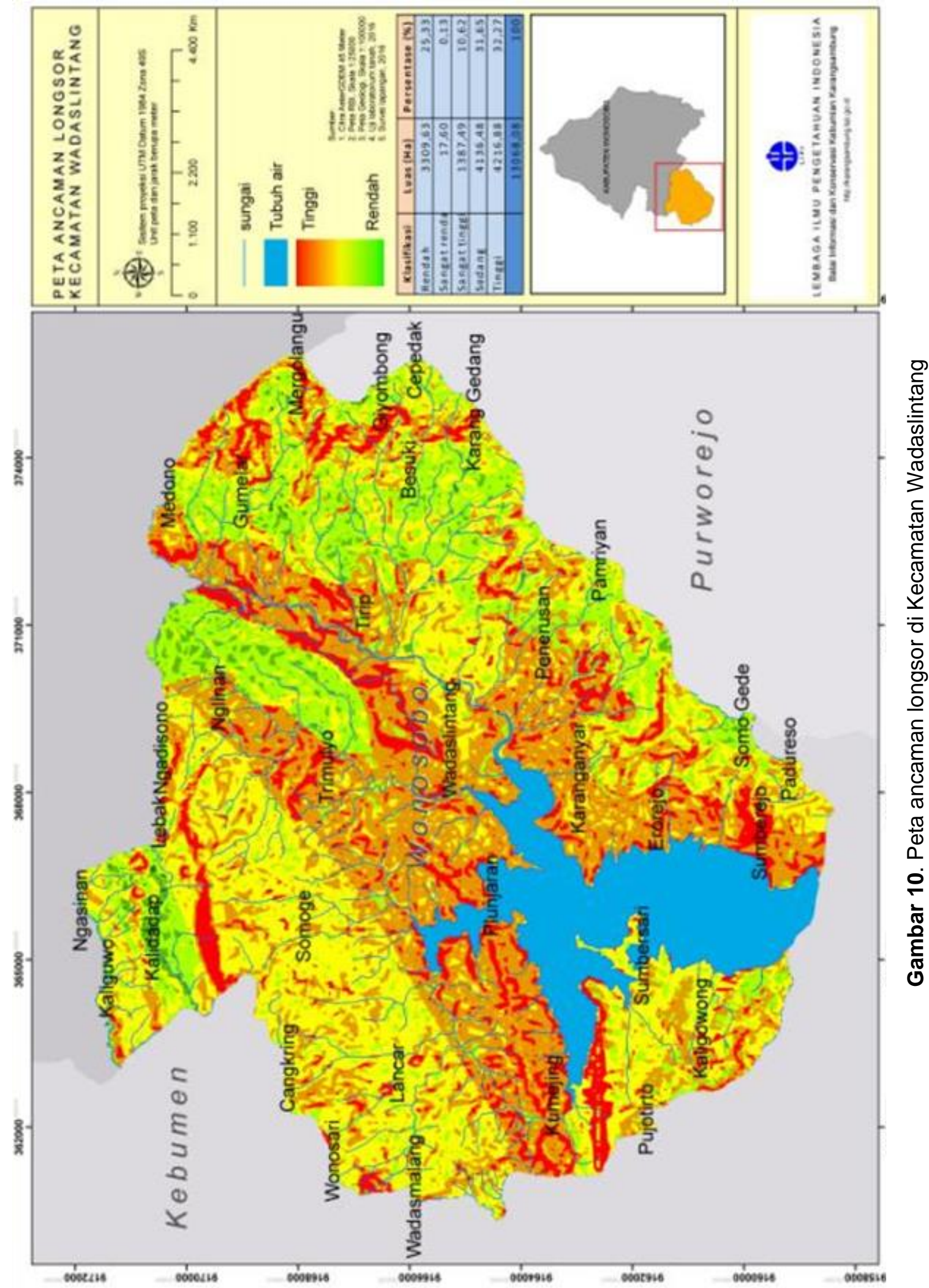


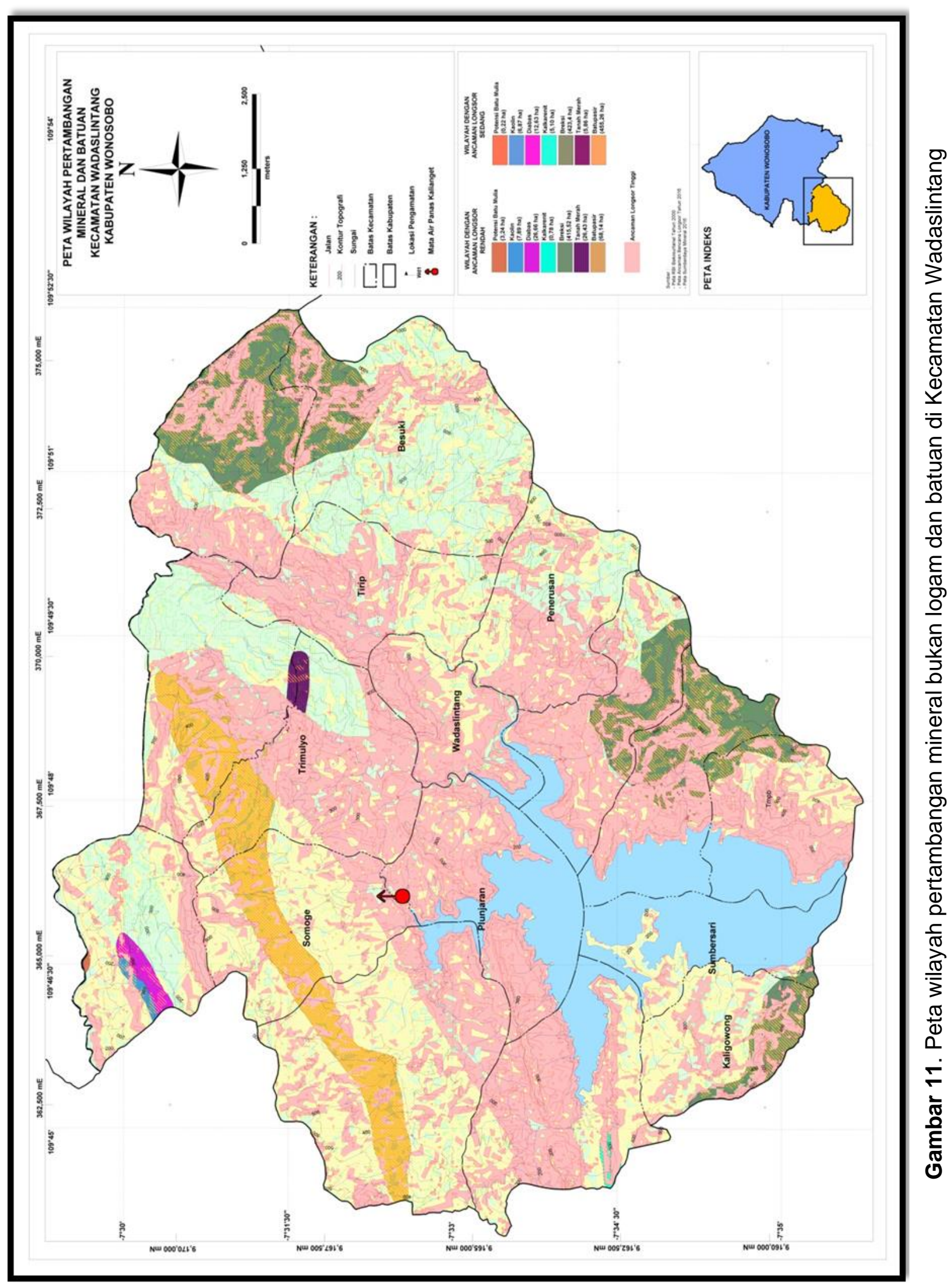




\section{KESIMPULAN}

Kondisi geologi Kecamatan Wadaslintang tersusun oleh batuan kompleks melange, Formasi Totogan, anggota tuff Formasi Waturanda, Formasi Waturanda, Formasi Penosogan, anggota breksi Formasi Peniron, Formasi Peniron dan intrusi diabas. Potensi tambangnya berupa kaolin, diabas, kalkarenit, breksi andesit, tanah merah, batupasir dan batu mulia. Kemiringan lereng mempunyai pengaruh $60 \%$ terhadap ancaman longsor, batuan $21 \%$, tanah $13 \%$ dan penggunaan lahan $6 \%$. Berdasarkan sebaran ancaman longsor yang terjadi pada zone tinggi maka luasan Wilayah Pertambangan rata-rata berkurang $28 \%$ dengan prosentase pengurangan terluas pada bahan tambang kalkarenit/batu lempeng sebesar 73,88\% akibat sebarannya pada kemiringan terjal serta faktor geologi, breksi $41,77 \%$ yang lebih dikontrol oleh keberadaannya pada kelerengan terjal. Sedangkan batu mulia prosentase pengurangannya $0 \%$, karena sebarannya berada pada dataran alluvial.

\section{UCAPAN TERIMA KASIH}

Atas terlaksananya penelitian ini penulis mengucapkan terima kasih pada Kepala Balai Informasi dan Konservasi Kebumian Karangsambung LIPI yang telah memberikan pendanaan penelitian serta seluruh anggota tim.

\section{DAFTAR PUSTAKA}

Anonim, 1989. SNI 03-0394-1989. Batu alam untuk bahan bangunan, Mutu dan Cara Uji. Pusat Penelitian dan Pengembangan Pemukiman, Departemen Pekerjaan Umum, Jakarta
Anonim, 2014; Peta Sebaran Komoditas Tambang Kabupaten Wonosobo, BAPPEDA Wonosobo (tidak dipublikasikan)

Asikin, S., Handoyo, A., Busono, H., Gafoer, S., 1992. Peta Geologi Lembar Kebumen, Jawa (Geologic Map of The Kebumen Quadrangle, Jawa), Lembar (Qudrangle) 1401-1, Skala (Scale) 1:100.000. Pusat Penelitian dan Pengembangan Geologi. Departemen Pertambangan dan Energi, Bandung

Ansori, C., Hadiwisastra, S., 2002; Karakteristik Fragmen Endapan Olistostrome di Karangsambung, Kebumen; Buku Geologi Jawa Tengah - Yogyakarta, Publikasi Khusus IAGI Komda Jateng-DIY, Yogyakarta

Ansori, C., Hastria, 2012; Potensi Bahan Tambang, Penataan Wilayah Usaha Pertambangan (WUP) dan Wilayah Pertambangan Rakyat (WPR) di Kebumen; Jurnal Teknologi Mineral dan Batubara, Puslitbang Teknologi Mineral dan Batubara, Kementrian ESDM, Bandung, Vol 8. No 3, September 2012, ISSN :1979-6560.

Condon, W. H., Pardyanto, L., Ketner, K., B. Amin, T. C. Gafoer, S., Samodra, H., 1996 Peta Geologi Lembar Banjarnegara dan Pekalongan (Geological Map of The Banjarnegara and Pekalongan Sheet, Jawa), Lembar (Qudrangle) 1408-4 dan 1409-1, Skala (Scale) 1:100.000. Pusat Penelitian dan Pengembangan Geologi. Departemen Pertambangan dan Energi, Bandung.

Suyanto, F.X., Roskamil; 1975; The hydrology and hydrocarbon aspect of south central java; Proceeding IAGI; Bandung 
Karnawati D., 2003; Manajemen Bencana Gerakan Tanah, Diktat Kuliah, Jurusan Teknik Geologi UGM.

Saaty T.L., 1980; The Analytic Hierarchy Process, Mc.Graw-Hill Book Company, New York
Soeria-Atmadja, R., Maury, R.C., Bellon, H.,Pringgopawiro, H.,Polve, M., Priadi, B., 1990; Tertiary Magmatic Belt in Jawa; Journal of Southeast Asian Earth Sciences, Vol 4, No 3, pp 171-187.

Suhala, S., dan Arifin, M. , 1997. Bahan Galian Industri, Pusat Penelitian dan Pengembangan Teknologi Mineral, Bandung, 366 hal.

$$
\begin{array}{ll}
\text { Diterima } & : 29 \text { September } 2017 \\
\text { Direvisi } & : 09 \text { Oktober } 2017 \\
\text { Disetujui } & : 29 \text { November } 2017
\end{array}
$$

